\title{
Dual-Roof Solar Greenhouse-A Novel Design for Improving the Heat Preserving Capacity in Northern China
}

\author{
Lilong Chai ${ }^{1,2 *}$, Baoju Wang1,2, Mingchi Liu' ${ }^{1,2}$, Zhanhui $\mathrm{Wu}^{1,2}$, Yong $\mathrm{Xu}^{1}$ \\ ${ }^{1}$ National Engineering Research Center for Vegetables, Beijing Academy of Agriculture and Forestry Sciences, \\ Beijing, China \\ ${ }^{2}$ Key Laboratory of Urban Agriculture (North), Ministry of Agriculture, Beijing, China \\ Email: "Ichaipurdue@gmail.com, ${ }^{*}$ liumingchi@nercv.org
}

Received 20 June 2014; revised 20 July 2014; accepted 3 August 2014

Copyright (C) 2014 by authors and Scientific Research Publishing Inc.

This work is licensed under the Creative Commons Attribution International License (CC BY).

http://creativecommons.org/licenses/by/4.0/

(c) (i) Open Access

\begin{abstract}
Dual-roof solar greenhouse, a new style of solar greenhouse, was designed in this study intending to reduce heat loss in cold time and improve land use efficiency in Beijing, the Capital city of China. Designing and applying the dual-roof greenhouse in metropolitan area had dual effects of saving energy and enhancing land use efficiency. According to the monitoring study and analysis conducted in winter of 2012, the averaged night temperature of south room was about $12.1^{\circ} \mathrm{C}$ in $\mathrm{De}$ cember, which was satisfying for growing average leaf vegetables. Total energy saved by dual-roof in whole winter was quantified as $1.1 \times 10^{7} \mathrm{MJ} \cdot \mathrm{yr}^{-1}$ (winter), potentially about $37.4 \mathrm{t}$ coal was saved in Beijing area during whole winter-growing period. Considering the application of north room, the land use efficiency was improved by $62.5 \%$ in dual-roof solar greenhouse.
\end{abstract}

\section{Keywords}

Agricultural Resource, Dual-Roof Greenhouse, Solar Energy, Land Use Efficiency, Heat Storage

\section{Introduction}

The Chinese solar greenhouse, characterized with east-west orientation, transparent camber south roof, and solid north roof and east and west walls, is utilized primarily in horticulture not only in northern China [1], but also in Canada [2]. This design of greenhouse can keep the sheltering plants from freezing in winter because of the "greenhouse effect". However, the healthy growing of plants needs additional heating during winter nights

\footnotetext{
*Corresponding authors.
}

How to cite this paper: Chai, L.L., Wang, B.J., Liu, M.C., Wu, Z.H. and Xu, Y. (2014) Dual-Roof Solar Greenhouse-A Novel Design for Improving the Heat Preserving Capacity in Northern China. Natural Resources, 5, 681-686. 
[3]-[5]. About 19300 ha of solar greenhouses had been constructed by the end of 2006 in Beijing [6], which consumed a huge quantity of energy in heating room [7] [8].

Conventional heating with fossil energy of coal or natural gas is non-sustainable, which is also potential greenhouse gas (GHG) contributor [9]-[11]. Overusing of fossil fuel in agricultural production has been directly or indirectly associated with the climate change, environmental pollution, and energy crisis. Therefore, developing and using energy-saving and clean energy storing technologies is important for reducing fossil energy use and GHG emissions [3] [12].

Dual-roof solar greenhouse is a new type of design, which differentiates itself from traditional single-roof solar greenhouse by adding another transparent camber roof in north side to form an extra space (north room) behind the northern wall. Two roofs share the same wall in the middle as the bearing structure. The objectives of this study are to 1) introduce a newly designed dual-roof solar greenhouse in Beijing; and 2) test and analyze the heating effect and heat preserving capacity of the greenhouse.

\section{Materials and Methods}

\subsection{Design of Dual-Roof Greenhouse}

Dural-roof greenhouse is a new form of solar greenhouse (Figure 1), which was designed for the purpose of reducing heat loss and improving land use efficiency. The newly designed dual-roof greenhouse locates in Fangshan District, Beijing (latitude $39^{\circ} 40^{\prime} \mathrm{N}$ ). The floor size of south room: length $\times$ width $=156 \mathrm{~m} \times 8 \mathrm{~m}\left(1248 \mathrm{~m}^{2}\right.$ ); north room: length $\times$ width $=156 \mathrm{~m} \times 5 \mathrm{~m}\left(780 \mathrm{~m}^{2}\right)$.

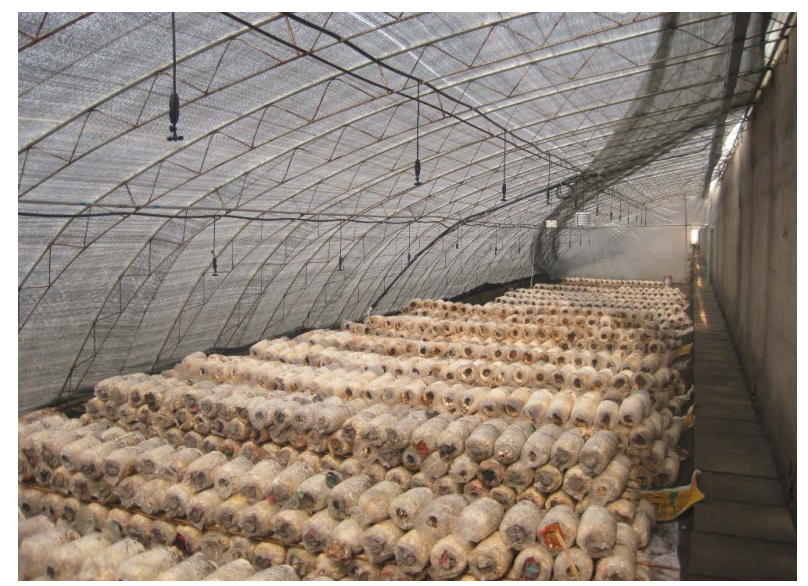

(a)

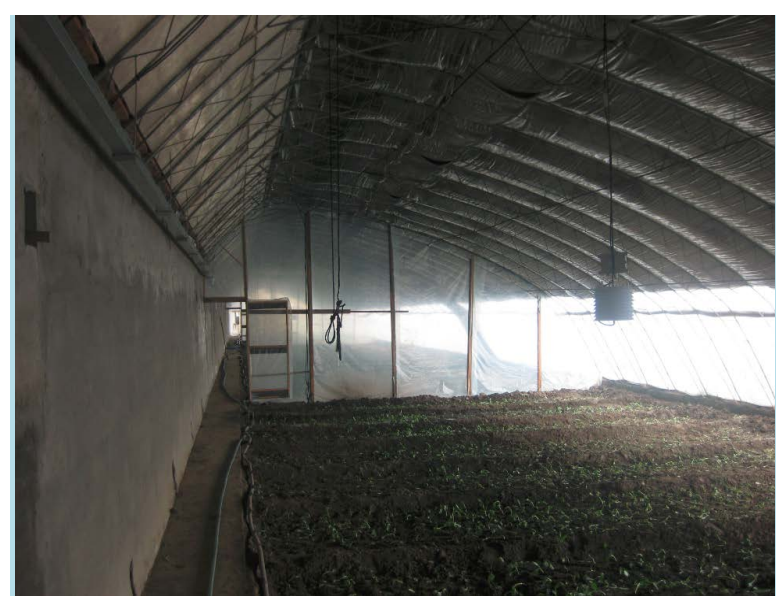

(b)

Figure 1. Dual-roof solar greenhouse. (a) North room $(\operatorname{area}=156 \times 5)$; (b) South room $(\operatorname{area}=156 \times 8)$. 


\subsection{Air and Heat Exchanging System}

About 26 circulating fans (totally 13 groups, 13 fans at the height of $1.8 \mathrm{~m}$ and 13 fans at the height of $0.5 \mathrm{~m}$ above ground, and two fans are one group) were installed in walls for exchanging air between south and north rooms. The position of vents and system was shown in Figure 2. Dual-roof solar greenhouse will transfer the extra heat from south room to north wall and north room for storing during day time when south room is warmed with the "greenhouse effect".

In the night, the heat stored in north wall and north room will, reversely, reheat the south room where grows thermophilic vegetables such as tomato and cucumber. Meanwhile, the north room could also be utilized to grow vegetables such as mushroom preferring lower lights and temperature environments. The heat exchanged between north and south rooms at each group fan [5] during day time were quantified with Equation (1).

$$
E_{\mathrm{fc}, \mathrm{k}, \tau}=V_{\mathrm{fc}, \mathrm{k}, \tau} \rho_{\mathrm{air}, \tau}\left(h_{\mathrm{fc}-\text { out }, \mathrm{k}, \tau}-h_{\mathrm{fc}-\mathrm{in}, \mathrm{k}, \tau}\right)
$$

where, $E_{\mathrm{fc}, \mathrm{k}, \tau}$ is heat exchanging rate of the fan group $\mathrm{k}$ during time $\tau, \mathrm{kJ} ; V_{\mathrm{fc}, \mathrm{k}, \tau}$ is volume of air flowed through the fan group $\mathrm{k}$ during time $\tau, \mathrm{m}^{3} ; \rho_{\mathrm{air}, \tau}$ is air density during time $\tau, \mathrm{kg} / \mathrm{m}^{3} ; h_{\mathrm{fc}-\mathrm{in}, \mathrm{k}, \tau}$ and $h_{\mathrm{fc}-\text { out }, \mathrm{k}, \tau}$ are mean air specific enthalpy at the inlet (air from north room) and outlet (air from south room) of fan unit k, respectively, during time $\tau, \mathrm{kJ} / \mathrm{kg}$.

The air specific enthalpy at each fan unit [5] was calculated with Equations (2) and (3).

$$
\begin{array}{r}
h_{\mathrm{fc}-\mathrm{in}, \mathrm{k}, \tau}=1.01 t_{\mathrm{fc}-\mathrm{in}, \mathrm{k}, \tau}+d_{\mathrm{fc}-\mathrm{in}, \mathrm{k}, \tau}\left(2501+1.85 t_{\mathrm{fc}-\mathrm{in}, \mathrm{k}, \tau}\right) \\
h_{\mathrm{fcc}-\text { out } \mathrm{k}, \mathrm{k}, \tau}=1.01 t_{\mathrm{fc}-\text { out } \mathrm{k}, \tau}+d_{\mathrm{fc}-\text { out }, \mathrm{k}, \tau}\left(2501+1.85 t_{\mathrm{fc}-\text { out }, \mathrm{k}, \tau}\right)
\end{array}
$$

where, $d_{\mathrm{fc}-\mathrm{in}, \mathrm{k}, \tau}$ and $d_{\mathrm{fc}-\mathrm{out}, \mathrm{k}, \tau}$ are mean air humidity ratio at the inlet (air from north room) and outlet (air from south room) of the fan group $\mathrm{k}$, respectively, during time $\tau, \mathrm{kg}$ (water) $/ \mathrm{kg}\left(\right.$ dry air); $t_{\mathrm{fc}-\mathrm{in}, \mathrm{k}, \tau}$ and $t_{\mathrm{fc}-\text { out }, \mathrm{k}, \tau}$ are mean air temperatures at the inlet and outlet of the fan unit k, respectively, during time $\tau,{ }^{\circ} \mathrm{C}$.

\subsection{Thermal-Environment Monitoring}

A monitoring study (Figure 3) was conducted in winter of 2012-2013 in the newly designed and constructed dual-roof solar greenhouse in order to assess the heat preserving capability. The south-room was grown with tomato, and the north room was grown with mushroom during the test. The indoor temperature, relative humidity, $\mathrm{CO}_{2}$ concentrations, solar radiation indoor and outsides were monitored and recorded with an integrated data-logger (Beijing PAIDE Science and Technology Development Co., Ltd., Beijing). Five monitoring locations (in the middle of the room in south-north direction, at height of $1.5 \mathrm{~m}$ above the floor) were chosen for south and north rooms, respectively. The time step of data recording was 30-min.

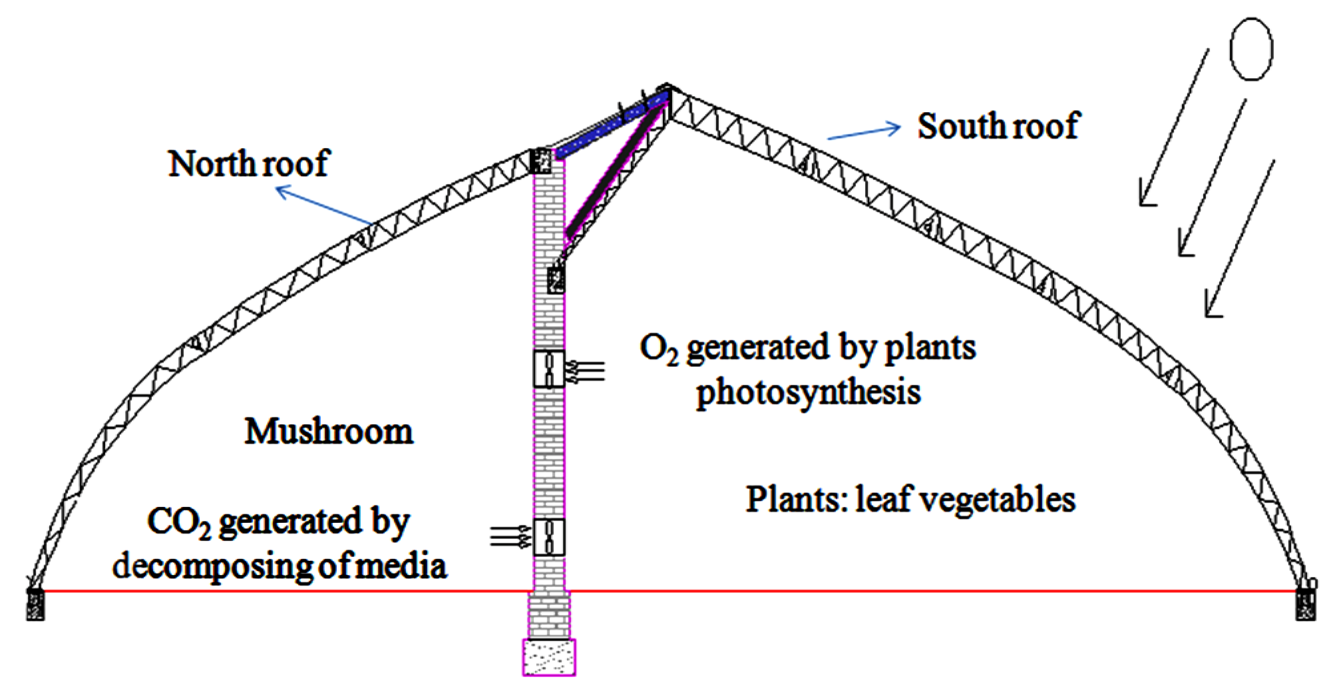

Figure 2. Diagram of air exchanging system in dual-roof solar greenhouse. 


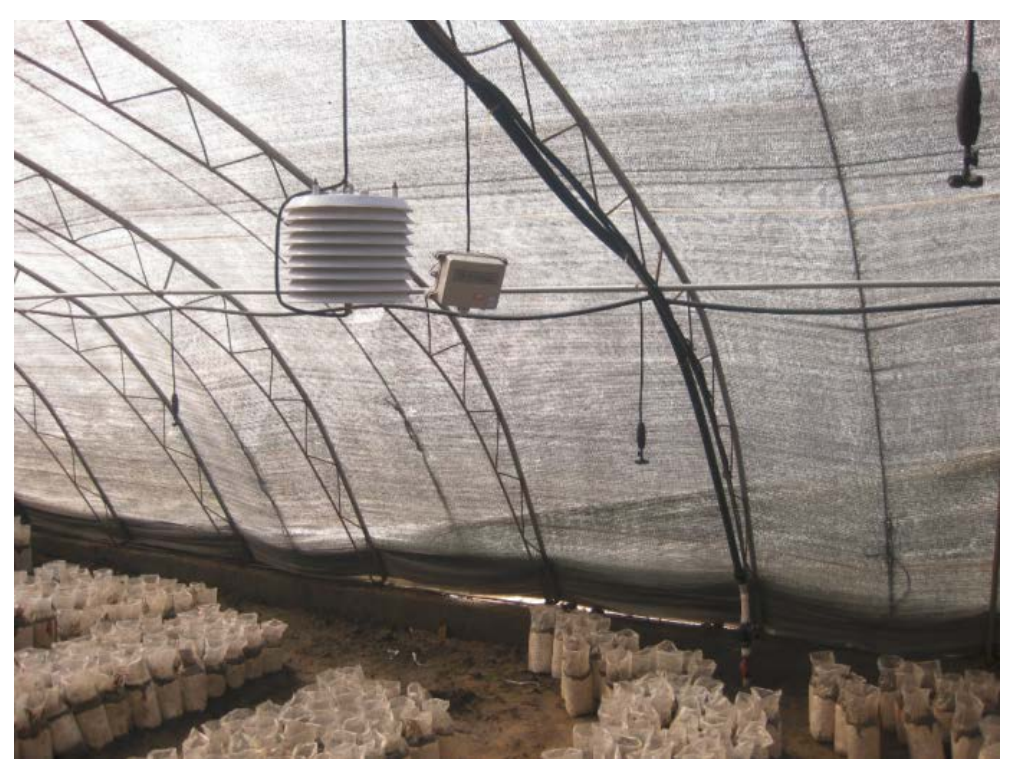

(a)

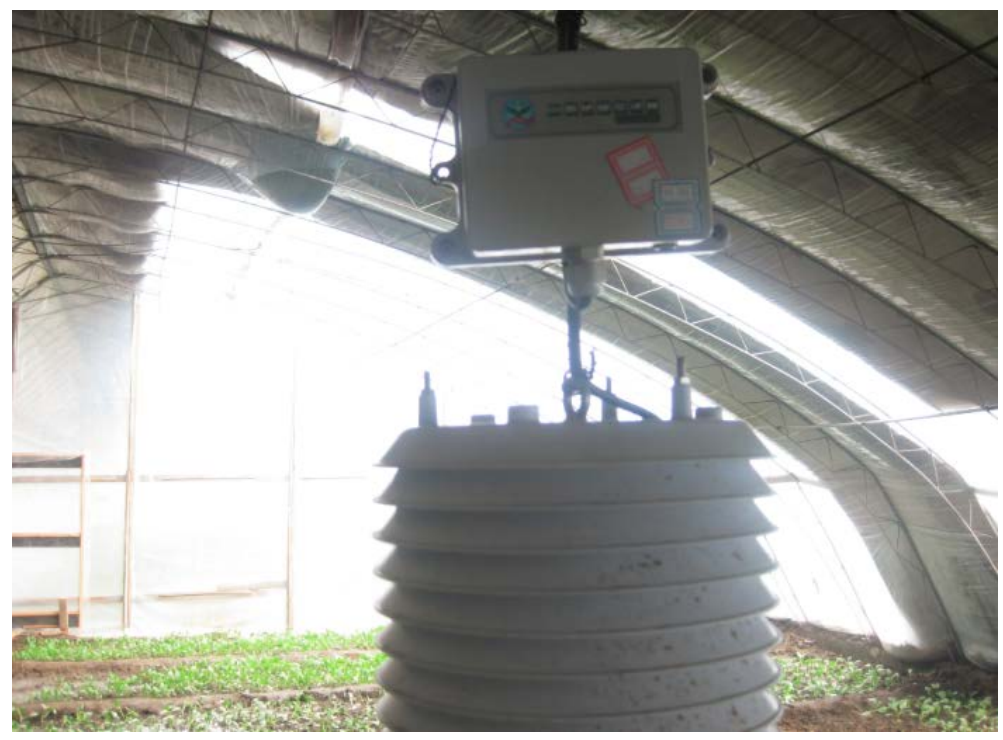

(b)

Figure 3. Monitoring systems and plants: (a) North room mushroom and sensors; (b) South room vegetables and sensors.

\section{Results and Discussions}

\subsection{Indoor and Outdoor Temperature}

The indoor air temperatures of south and north rooms collected in December of 2012 were shown in Figure 4.

From Dec.1st to 5 th, averaged temperature in south, north rooms and outdoor were $12.1^{\circ} \mathrm{C}, 0.6^{\circ} \mathrm{C}$, and $-2.9^{\circ} \mathrm{C}$, respectively. South room temperature is satisfying the basic requirement for leaf vegetables growing. There was $15^{\circ} \mathrm{C}$ difference between south room and outdoor. Besides, the highest $\mathrm{T}$ in south room can be reached at $30^{\circ} \mathrm{C}$ at noon with the increasing of solar radiation. The exchanged $\mathrm{CO}_{2}$ between north and south rooms and its influence on plants growing will be studied in the near future.

\subsection{Heat Preserved and Land Use Efficiency}

It is reported that the heat load of solar greenhouse is about 0.065 to $0.075 \mathrm{~kW} / \mathrm{m}^{2}$ in Beijing area and heating 


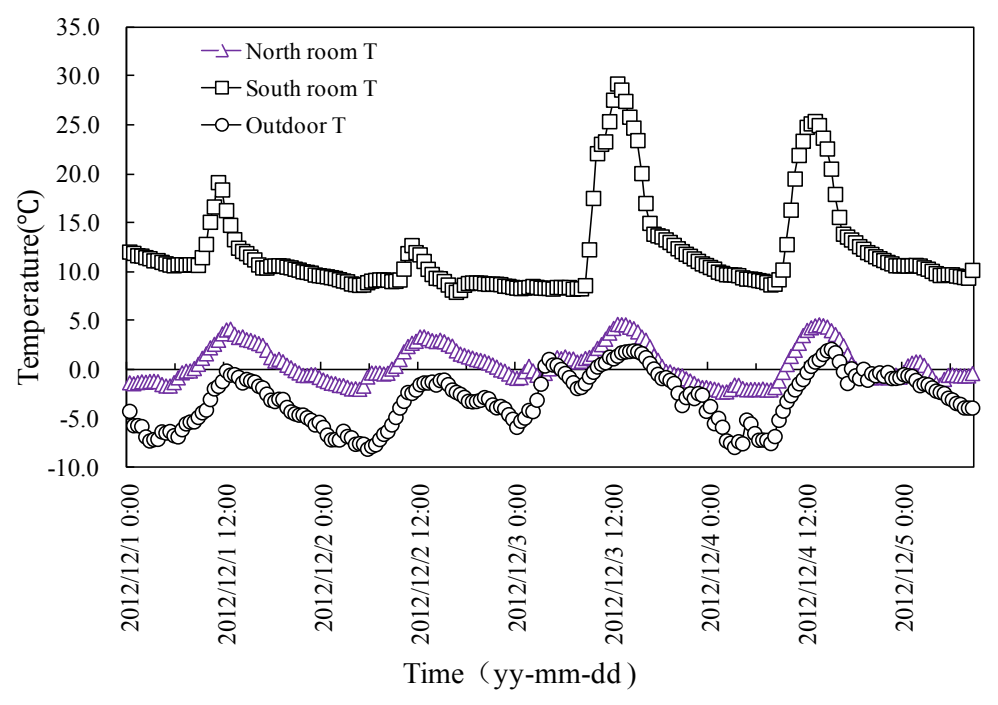

Figure 4. Indoor and outdoor temperature in winter.

period is $146 \mathrm{~d}$ [6], which means the energy preserved by dual-roof solar greenhouse is about $87 \mathrm{~kW}$ or 7547 $\mathrm{MJ} / \mathrm{d}$ (floor area of south room is $1248 \mathrm{~m}^{2}$ ). Total energy saved by dual-roof in whole winter was about $1101994 \mathrm{MJ}$ (about $1.1 \times 10^{7} \mathrm{MJ}$ ). As the heat value of standard coal is $29,306 \mathrm{MJ} / \mathrm{t}$, about $37.4 \mathrm{t}$ coal was saved for heating the greenhouse.

Traditional designing of solar greenhouse has to consider shade from frontier greenhouse, therefore, the area between greenhouses usually cannot be utilized [12] (Ma et al., 2006). However, the dual-roof solar greenhouse designed in this study make used of the land area fully by building the north room. Considering the ratio of north room and south, the land use efficiency was improved by $62.5 \%$, which is very important for the fast growing metropolitan city like Beijing.

\section{Conclusions}

The dual-roof solar greenhouse, a new style of Chinese solar greenhouse, was designed in this study intending to satisfy the purpose of reducing heat loss in cold time and improving land use efficiency in metropolis area, such as Beijing, the Capital of China. Dual-roof solar greenhouse was equipped with air-exchanging system, which improved the function of heat transferring between south and north rooms. The exchanged $\mathrm{CO}_{2}$ between north and south rooms and its influence on plants growing will be studied in the near future.

South room of dual-roof greenhouse has the averaged $\mathrm{T}$ of $12.1^{\circ} \mathrm{C}$ in December, which is satisfying the basic requirement for growing leaf vegetables. There is $15^{\circ} \mathrm{C}$ difference between south room and outdoor. Total energy saved by dual-roof in whole winter could be 1101994 MJ per year during winter; potentially about 37.4 t coal is saved in growing vegetables in Beijing area. Considering the ratio of north room and south, the land use efficiency has been improved by $62.5 \%$, which is very important for the fast growing metropolitan city like Beijing.

\section{Acknowledgements}

This study was sponsored by the Beijing Natural Science Foundation (6132011), Young Researcher Foundation (QNJJ201212) in Beijing Academy of Agricultural and Forestry Sciences, and Twelve-Five-Year National Science and Technology Support Program (2011BAD12B01), Ministry of Science and Technology, P.R. China.

\section{References}

[1] Tong, G., Wang, T., Bai, Y. and Liu, W. (2003) Heat Transfer Property of the Wall in Solar Greenhouse. Transactions of the Chinese Society of Agricultural Engineering, 19, 186-189.

[2] Beshada, E., Zhang, Q. and Boris, R. (2006) Winter Performance of a Solar Energy Greenhouse in Southern Manitoba. Canadian Biosystems Engineering, 48, E1-E8.

[3] Ma, C. and Miao, X. (2005) Agricultural Bio-Environment Engineering. China Agriculture Press, Beijing. 
[4] Chai, L., Ma, C., Zhang, X., Qu, M., Chen, Q. and Yu, F. (2008) Experimental Investigation and Performance Analysis on Ground Source Heat Pump System for Greenhouse Cooling. Transactions of the Chinese Society of Agricultural Engineering, 24, 150-154.

[5] Chai, L., Ma, C. and Ni, J.Q. (2012) Performance Evaluation of Ground Source Heat Pump System for Greenhouse Heating in Northern China. Biosystems Engineering, 111, 107-117. http://dx.doi.org/10.1016/j.biosystemseng.2011.11.002

[6] Beijing Statistical Bureau (2008) Beijing Statistical Yearbook 2008. Chinese Statistical Press, Beijing.

[7] Chai, L., Ma, C., Zhang, Y., Wang, M., Ma, Y. and Ji, X. (2010) Energy Consumption and Economic Analysis of Ground Source Heat Pump Used in Greenhouse in Beijing. Transactions of the Chinese Society of Agricultural Engineering, 26, 249-254.

[8] Chai, L., Ma, C., Liu, M., Wang, B., Wu, Z. and Xu, Y. (2014) Carbon Footprint of Ground Source Heat Pump System for Greenhouse Heating Based on Life Cycle Assessment Method. Transactions of the Chinese Society of Agricultural Engineering, 30, 149-155.

[9] Bot, G.P.A. (2001) Developments in Indoor Sustainable Plant Production with Emphasis on Energy Saving. Computers and Electronics in Agriculture, 30, 151-165. http://dx.doi.org/10.1016/S0168-1699(00)00162-9

[10] Bartzanas, T., Tchamitchian, M. and Kittas, C. (2005) Influence of the Heating Method on Greenhouse Microclimate and Energy Consumption. Biosystems Engineering, 91, 487-499. http://dx.doi.org/10.1016/j.biosystemseng.2005.04.012

[11] Sethi, V.P. and Sharma, S.K. (2008) Survey and Evaluation of Heating Technologies for Worldwide Agricultural Greenhouse Applications. Solar Energy, 82, 832-859. http://dx.doi.org/10.1016/j.solener.2008.02.010

[12] Ma, C., Zhang, J., Qin, M. and Liu, R. (2006) Theoretical Analysis Using the Method of Energy Equilibrium in Covering Layer and Validation of the Overall Heat Transfer Coefficient of Greenhouse Covering Materials. Transactions of the Chinese Society of Agricultural Engineering, 22, 1-5. 
Scientific Research Publishing (SCIRP) is one of the largest Open Access journal publishers. It is currently publishing more than 200 open access, online, peer-reviewed journals covering a wide range of academic disciplines. SCIRP serves the worldwide academic communities and contributes to the progress and application of science with its publication.

Other selected journals from SCIRP are listed as below. Submit your manuscript to us via either submit@scirp.org or Online Submission Portal.
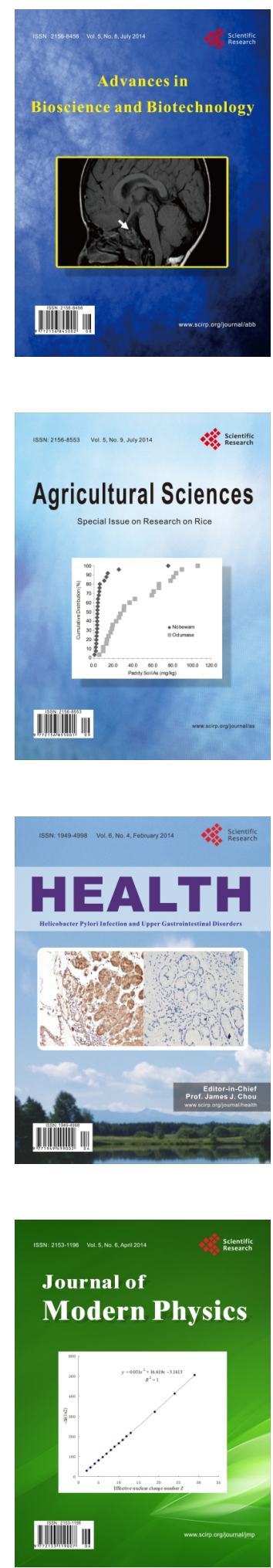
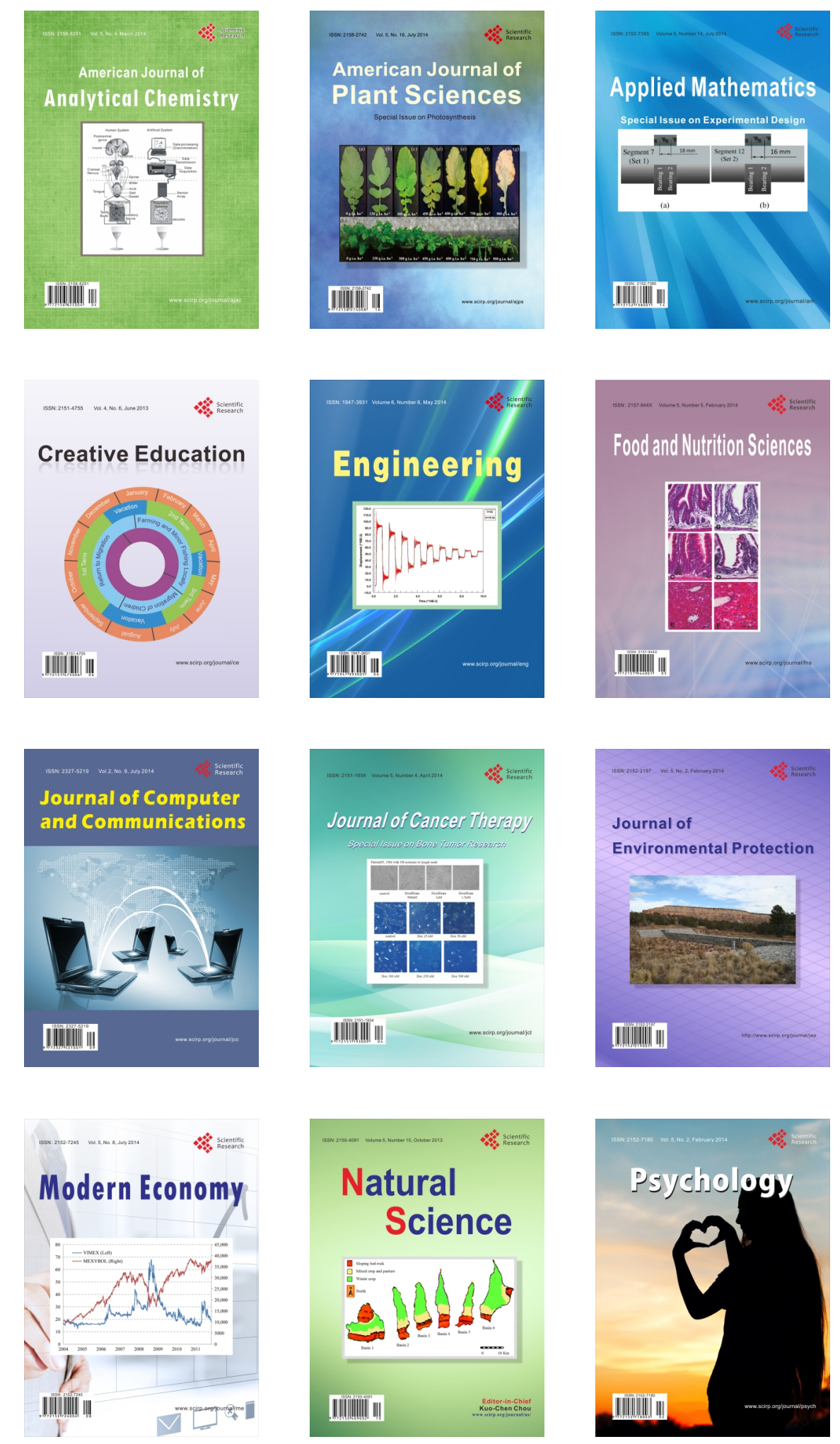